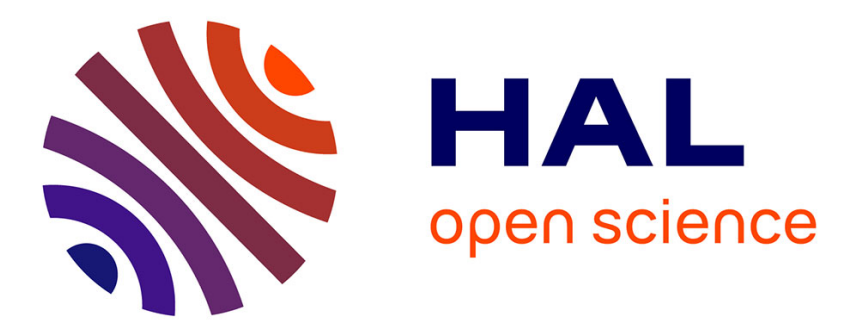

\title{
Contemporaneous multi-scale structures in the Montagne des Mémises (Préalpes du Chablais, Haute-Savoie, France)
}

Anne Guyomard, Jean-Yves Josnin, Jean-Claude Hippolyte, Serge Fudral

\section{To cite this version:}

Anne Guyomard, Jean-Yves Josnin, Jean-Claude Hippolyte, Serge Fudral. Contemporaneous multiscale structures in the Montagne des Mémises (Préalpes du Chablais, Haute-Savoie, France). Swiss Journal of Geosciences, 2009, 102 (1), pp.3-14. halsde-00396157

\section{HAL Id: halsde-00396157 \\ https://hal.science/halsde-00396157}

Submitted on 27 Nov 2021

HAL is a multi-disciplinary open access archive for the deposit and dissemination of scientific research documents, whether they are published or not. The documents may come from teaching and research institutions in France or abroad, or from public or private research centers.
L'archive ouverte pluridisciplinaire HAL, est destinée au dépôt et à la diffusion de documents scientifiques de niveau recherche, publiés ou non, émanant des établissements d'enseignement et de recherche français ou étrangers, des laboratoires publics ou privés. 


\title{
Contemporaneous multi-scale structures in the Montagne des Mémises (Préalpes du Chablais, Haute-Savoie, France)
}

\author{
Anne Guyomard ${ }^{1,2, *}$, Jean-Yves Josnin ${ }^{1}$, JeAn-Claude Hippolyte ${ }^{3}$ \& Serge Fudral ${ }^{1}$
}

Key words: strike-slip faults, normal faults, fault striation analysis, conical folds, paleostress, stress permutation, Montagne des Mémises, Préalpes du Chablais, France

\begin{abstract}
The Montagne des Mémises, which lies to the south of Lake Geneva between Thonon-les-Bains (France) and the Rhone Valley (Switzerland), belongs to the frontal part of the Préalpes du Chablais klippe. It is composed of an upright syncline with a curved axis that is bordered by two left-lateral strike-slip faults, the Bonnevaux-Col du Pertuis fault to the west, and the Rhone Valley fault to the east. The south-western part of the syncline is characterized by tilted blocks separated by listric and sinistral strike-slip faults that trend $\mathrm{N} 20^{\circ} \mathrm{E}$ and dip West. These faults are well developed and clearly visible only along the north-western part of the syncline, that is, along the outer part of the fold. Moreover, asymmetrical and conical metre-sized folds are present within early Cretaceous limestones close to the N to NNEtrending faults. Bedding plane relationships and fault population analyses confirm that the compressive-strike slip structures and the normal faults are contemporaneous.

The faults were formed under a strike-slip regime with $\sigma_{1}$ between $\mathrm{N} 150^{\circ} \mathrm{E}$ and $\mathrm{N} 160^{\circ} \mathrm{E}$. The strike-slip movement was mostly along sinistral faults oriented $\mathrm{N}$ to NNE. A population analysis of the normal faults indicates directions of extension parallel to the fold structures $\left(\sigma_{3}\right.$ between $\mathrm{N} 40^{\circ} \mathrm{E}$ and $\mathrm{N} 60^{\circ} \mathrm{E}$ ). It shows that the extension is the result of the permutation of the $\sigma_{1}$ and $\sigma_{2}$ stresses of the strike-slip phase ( $\sigma_{3}$ remaining constant).

During the multiphase tectonic evolution of the Prealps, the deformations described in the present article contributed, within a continuum, to the formation of the klippe and created an exemplary set of structures in the Massif des Mémises. From a more general point of view, it appears likely that such contemporaneous multi-scale structures exist along the entire length of the western Alpine arc.
\end{abstract}

\section{RÉSUMÉ}

Le présent travail est une contribution à la connaissance structurale des Préalpes du Chablais (France). Il concerne la partie frontale de la klippe et plus précisément le massif des Mémises (Préalpes Médianes Plastiques). Ce massif est essentiellement formé par un synclinal perché, à axe courbe à concavité tournée vers l'est, plongeant vers le sud-ouest à l'ouest et vers le nord-est à l'est, et limité par deux accidents décrochants senestres, la faille col de Bonnevaux - col du Pertuis à l'ouest et l'accident du Rhône à l'est.

Les nouvelles études multidisciplinaires d'ordre tectonique, hydrologique et hydrogéologique que nous avons menées révèlent trois grands types de structures, de nature et d'échelle différentes, dont l'analyse démontre la contemporanéité ou du moins la compatibilité mécanique. La structure synclinale des Mémises apparaît, à plus petite échelle, découpée en blocs basculés par des failles listriques. Celles-ci sont quasi perpendiculaires à l'axe du pli et particulièrement bien observables sur son flanc nord. Des mouvements décrochants sénestres sont par ailleurs identifiés sur ces fractures et sur d'autres, toujours de direction N à NNE. Ces accidents s'accompagnent enfin de petits plis métriques asymétriques et coniques, bien individualisés dans les calcaires en plaquettes du Néocomien. L'analyse structurale, et notamment l'analyse des populations de failles, accrédite la compatibilité mécanique et la probable contemporanéité des structures compressives-décrochantes et extensives. L'extension locale résulterait alors d'une adaptation de la déformation plicative. Les failles ont fonctionné en régime décrochant avec $\sigma_{1}$ compris entre $\mathrm{N} 150^{\circ} \mathrm{E}$ et $\mathrm{N} 160^{\circ} \mathrm{E}$ et un mouvement décrochant principalement sur des failles sénestres orientées $\mathrm{N}$ à NNE. L'analyse des failles normales révèle une direction d'extension parallèle aux structures plicatives $\left(\sigma_{3}\right.$ compris entre $\mathrm{N} 40^{\circ} \mathrm{E}$ et $\mathrm{N} 60^{\circ} \mathrm{E}$ ). Elle montre que l'extension résulte de la permutation des contraintes $\sigma_{1}$ et $\sigma_{2}$ de la phase décrochante ( $\sigma_{3}$ restant constant).

Dans l'évolution tectogénétique polyphasée des Préalpes, les déformations décrites participent, au cours d'un continuum, à la structuration de la klippe et confèrent au massif des Mémises un cadre exemplaire d'observations. D'un point de vue plus général, il est vraisemblable que de telles structures multi-échelles, contemporaines, existent tout au long de la courbure de l'arc alpin occidental.

\section{Introduction}

A large number of structural studies have been carried out in the Préalpes Médianes Romandes during the last three decades (Plancherel \& Weidmann 1972; Plancherel 1976,
1979; Mosar 1988, (a \& b), 1989, 1991, 1994, 1997, 1999, 2002, Mettraux \& Mosar 1989; Mosar \& Bore 1992, 1995; Mosar et al. 1996). However, most of the studies carried out in the Préalpes Médianes du Chablais during this period were large scale (Plancherel 1990; Borel \& Mosar 2000) or specifically

\footnotetext{
${ }^{1}$ Laboratoire EDYTEM, Université de Savoie, UMR 5204 CNRS, campus scientifique, 73376 Le Bourget du Lac cedex, France.

${ }^{2}$ Syndicat Intercommunal d'Aménagement du Chablais, 2 Avenue des Allobroges, Square Voltaire-BP33, 74201 Thonon-les-Bains Cedex, France.

${ }^{3}$ CEREGE, UMR-6635 CNRS, BP80, 13545 Aix en Provence Cedex 4, France.

*Corresponding author: anne.guyomard@univ-savoie.fr, anne.guyomard@gmail.com
} 
focused on neo-tectonics (Raymond et al. 1996; Delacou et al. 2005).

The aim of the present study was to establish the relationships and age of the multi-scale structures observed in the syncline that forms the Montagne des Mémises, and to relate these structures to large-scale tectonic structures. Our structural mapping was complemented by fault striation measurements (Guyomard 2006). Paleostress reconstructions were performed by a combination of two methods, originally proposed by Angelier $(1990,1991)$ and by Etchecopar et al. (1981).

We begin by describing the geographical and tectonic setting of the Montagne des Mémises, and then we present our macrostructural data and their relationships. Paleostress analysis was used to constrain the geodynamics and to reveal the chronological relationships between the macro-structures. Finally, we discuss the results within the regional tectonic setting.

\section{The geological setting of the Montagne des Mémises.}

The Montagne des Mémises, which lies on the southern shore of Lake Geneva, east of Thonon-les-Bains (France), forms part of the Préalpes Médianes. On the basis of sedimentary facies and structural criteria, the Préalpes Médianes have been di- vided into two different units (Lugeon \& Gagnebin 1941): the outer Préalpes Médianes Plastiques and the inner Préalpes Médianes Rigides (Fig. 1). The Préalpes Médianes Plastiques is a marl-rich formation consisting of Triassic gypsum horizons and dolomitic limestones, Liassic spathic and siliceous limestones, Dogger marly horizons, Malm and Neocomian limestones and Late Cretaceous to Tertiary nodular and well-bedded horizons with marls and fine-grained sandstones. The whole succession is up to 1,700 meters thick (Sartiges 1978). The Montagne des Mémises, which is composed of Liassic and Malm units, belongs to the frontal part of the Préalpes Medianes Plastiques. The variation in lithology and rheology of the sediments in the sequence influenced the deformation style of the area.

\section{Large- to meso-scale structures in the Montagne des Mémises.}

Superficially, the Montagne des Mémises appears to consist of a series of simple folds (from south to north: the Lanches anticline, the Memises syncline and the Thollon anticline, Fig. 2) that are covered to a greater or lesser extent by Quaternary deposits. However, detailed investigation shows that these structures are much more complex.

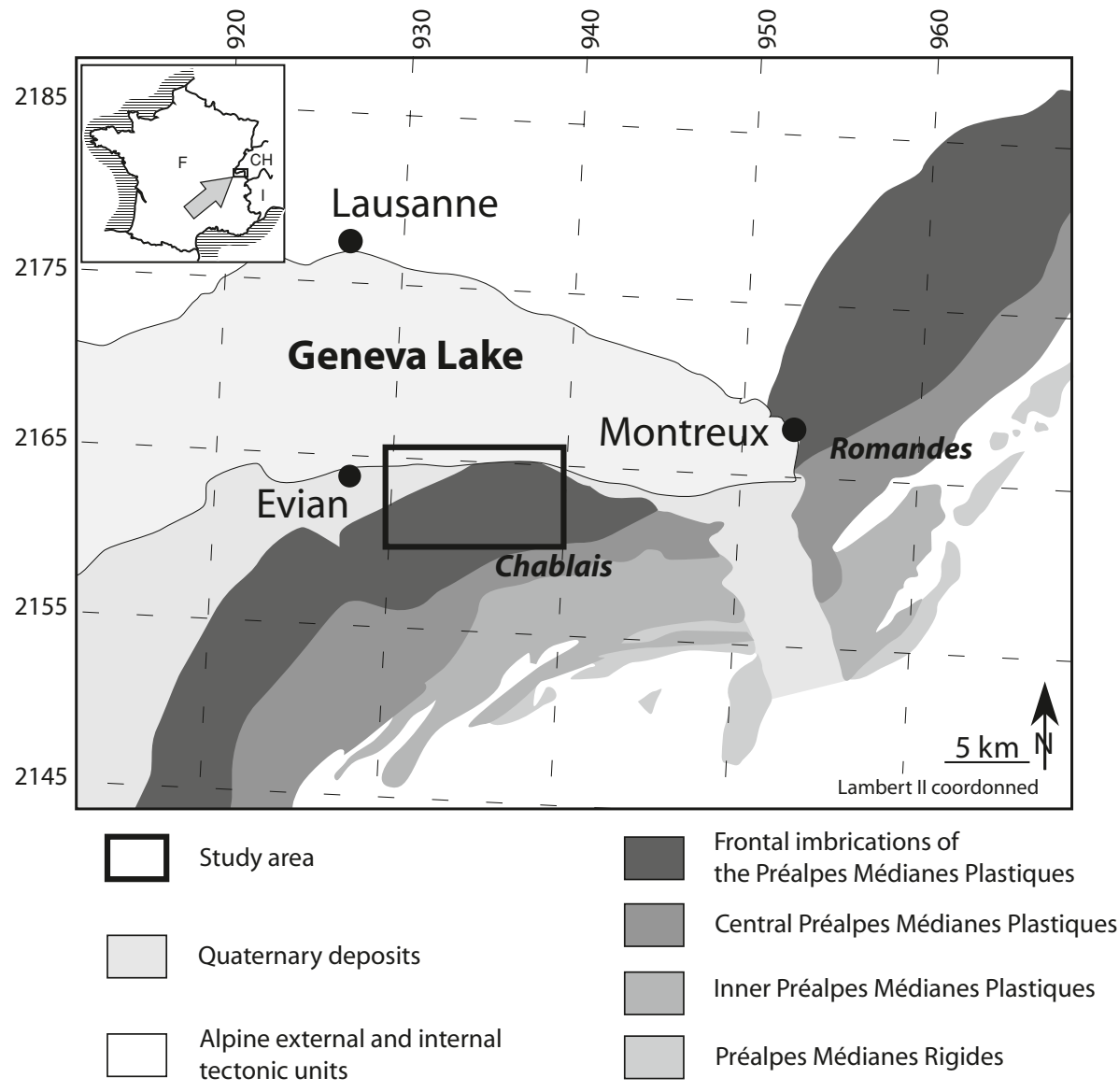

Fig. 1. Geological setting of the study area (Montagne des Mémises).

4 A. Guyomard et al. 

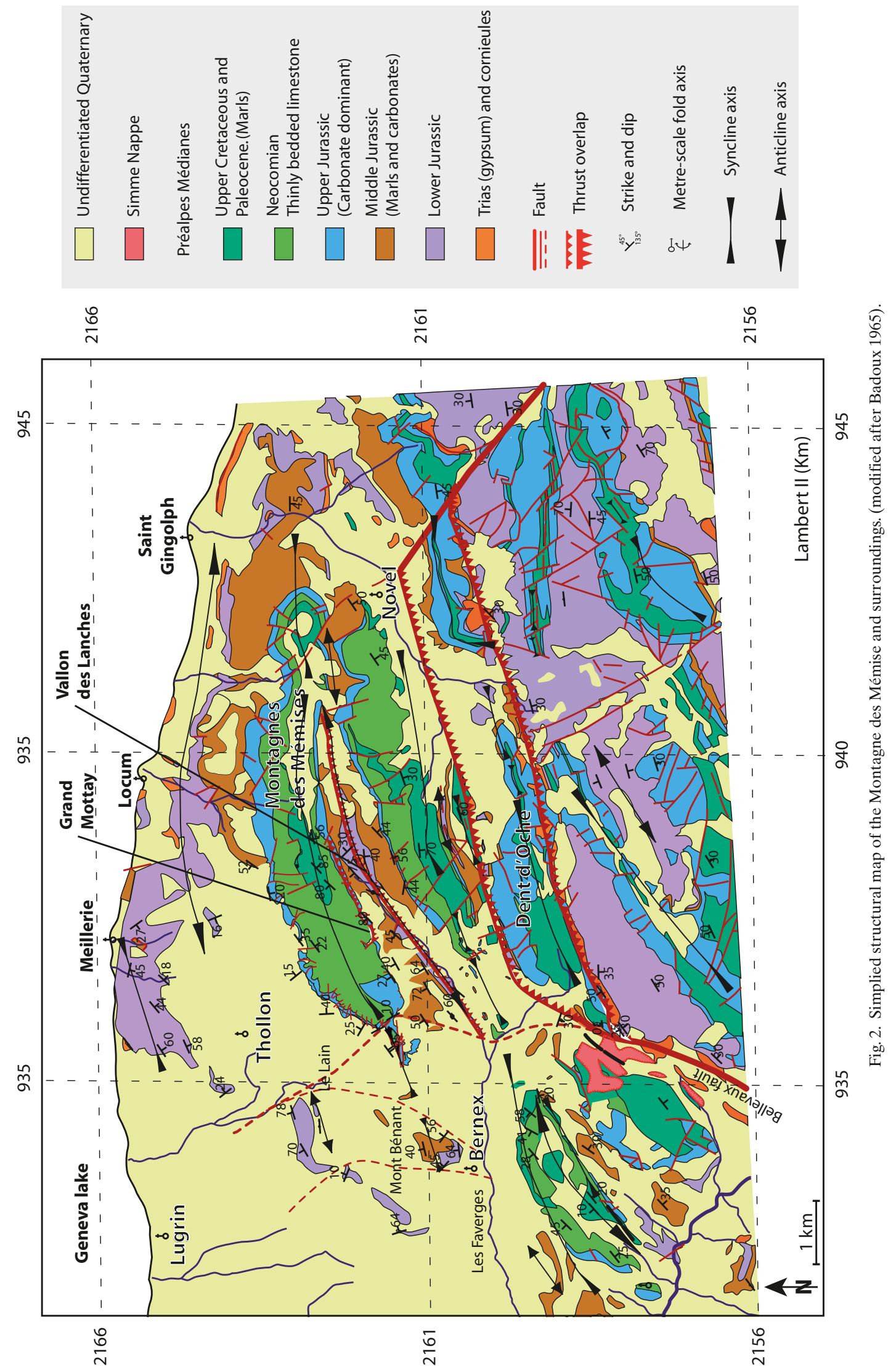


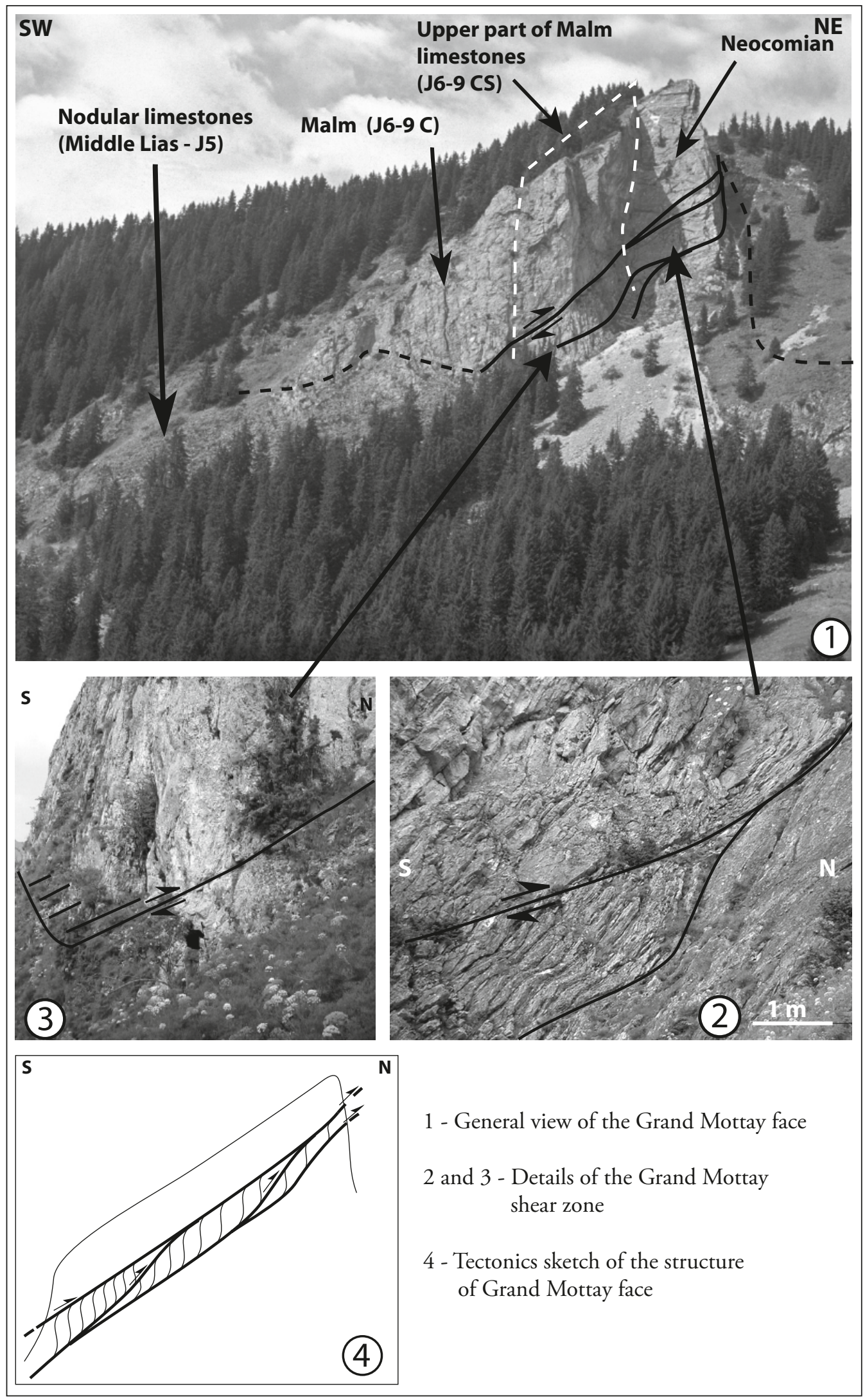

Fig. 3. Structures of southern flank the Grand Mottay. 


\subsection{The Lanches anticline.}

The Lanches anticline (Fig. 2) is a tight, northward dipping conical anticline with an axis that trends $\mathrm{N} 60^{\circ} \mathrm{E}$ in the area to the west of the Col des Lanches, but that dips SW and trends $\mathrm{N} 90^{\circ} \mathrm{E}$ to the east of the Col. On the western flank of the Haut des Lanches area, south-dipping thrusts have injected cornieules into Rhaetian calcareous coquina beds. Thrust faults and small asymmetric folds can be observed. The axes of these folds are oriented $\mathrm{N} 55^{\circ} \mathrm{E}$ and plunge towards NE. The Lanches anticline is very likely a fault-propagation fold similar to structures described within the Préalpes Médianes Romandes (Mosar 1991 \& 1994).

\subsection{The Mémises syncline.}

Three areas are interesting from a structural point of view: the southern flank of the Montagne des Mémises at Grand Mottay, the faces of the north ridge of the Montagne des Mémises, and the northern flank of the Mémises syncline.

1) The southern flank of the Montagne des Mémises at Grand Mottay is marked by an eastward-dipping to sub-vertical thrust together with meter-scale flexural-slip duplexes (Fig. 3). The thrust trends $\mathrm{N} 140^{\circ} \mathrm{E}$ and dips $25^{\circ}$ South. Examination of calcite steps indicates a top- to $-\mathrm{N}$ sense of movement. A small number of fibrous calcite veins are present. Tectonic stretching of this flank caused thinning of the Malm sequence. In the area between the Vallon des Lanches and the Mémises syncline, the upper part of the cherty Malm sequence lies directly upon Argovian ammonite-bearing nodular limestones and the whole MalmArgovian sequence is only $35-\mathrm{cm}$ thick, which is in marked contrast to the one hundred metres or more recorded in other parts of the study area.

2) On the northern flank of the Montagne des Mémises, we observed asymmetrical metre-scale folds. These folds were also observed by Badoux and Mercanton (1962) and by Sartige (1978). Similar structures have been described in the south-western part of the Préalpes Romandes and interpreted as second-order disharmonic folds (Mosar 1991, 1994). We observed $\mathrm{N} 55^{\circ}$ E-trending disharmonic folds in Raethian layers within anticlines, but the asymmetric folds that occur in the Late Cretaceous formations probably have another origin, as these folds are conical, trend $\mathrm{N} 40^{\circ} \mathrm{E}$ to $\mathrm{N} 80^{\circ} \mathrm{E}$ and occur close to strike-slip faults (Fig. 4). The folding is contemporaneous with the development of the schistosity and we therefore infer that the folds are the result of strike-slip faulting.

3) The northern flank of the Mémises syncline is affected by normal faults (Fig. 4) that sole out westward within the Dogger calcareous marls. They run perpendicular to the axis of the western part of the Mémises syncline and divide the syncline into numerous blocks that give an eastward tilt to the stratigraphic sequence. The fact that they are perpendicular to the syncline suggests that they result from lateral accommodation of the folding (i.e. reflect orogen-parallel extension during convergence). Moreover, to either side of the syncline, normal faults disappear and compressional deformation prevails, which supports the hypothesis of local strain accommodation.

\section{Fault population analysis}

\subsection{Method}

The study area included seven localities suitable for fracture analysis, and two more were found $15 \mathrm{~km}$ and $25 \mathrm{~km}$ further west. These nine localities are labeled A to I (Fig. 5). At each locality, between 8 and 25 striated fault planes with clear striation and direction indicators were measured, thus giving large enough data sets to allow accurate paleostress calculations to be made. In order to achieve a complete analysis, we used two calculation methods to determine the standard deviations of the stress axis orientations: the Direct Method (Etchecopar 1981) and the Direct Inversion Method (INVD, Angelier 1990, 1991). Both methods are based on the angle between the calculated shear stress and the measured striations; but the Direct Inversion Method also takes into account the relative friction on the fault planes.

These methods were used to determine the four components of the stress tensors, that is to say, the orientations and dips of the three principal stress axes and the ratios between the stress values. The principal stress axes and the striated fault planes were plotted on the lower hemispheres of stereograms (Fig. 5). We only present results for which there was agreement between the two calculation methods. The diagrams in Fig. 5 are labeled using two letters to identify the locality name and the type of faulting (e.g., $\mathrm{n}$ for normal faulting). A third letter was added to differentiate between different diagrams for a single locality (e.g., Fna and Fnb).

Our data provides the first paleostress results for the Montagne des Mémises. It should be noted that we did not find any evidence of polyphase deformation, suggesting that the reconstructed paleotress axes have not been tilted by successive events. Although we observed striations with slightly different orientations on different parts of a single fault plane, there was never any clear superposition of these striations.

\subsection{Results}

Our paleostress reconstruction reveals two types of stress regime: a strike-slip to compressional regime with $\sigma_{1}$ trending NNW-SSE, and an extensional regime with $\sigma_{3}$ almost parallel to the fold axes of the Mémises structure.

\subsubsection{Strike-slip to compressional regimes}

The paleostress axes in fault diagrams B, E, G, H and I (Fig. 5) correspond to a strike-slip stress regime with $\sigma_{1}$ trending NNWSSE. Two of the stress axes are approximately horizontal and 

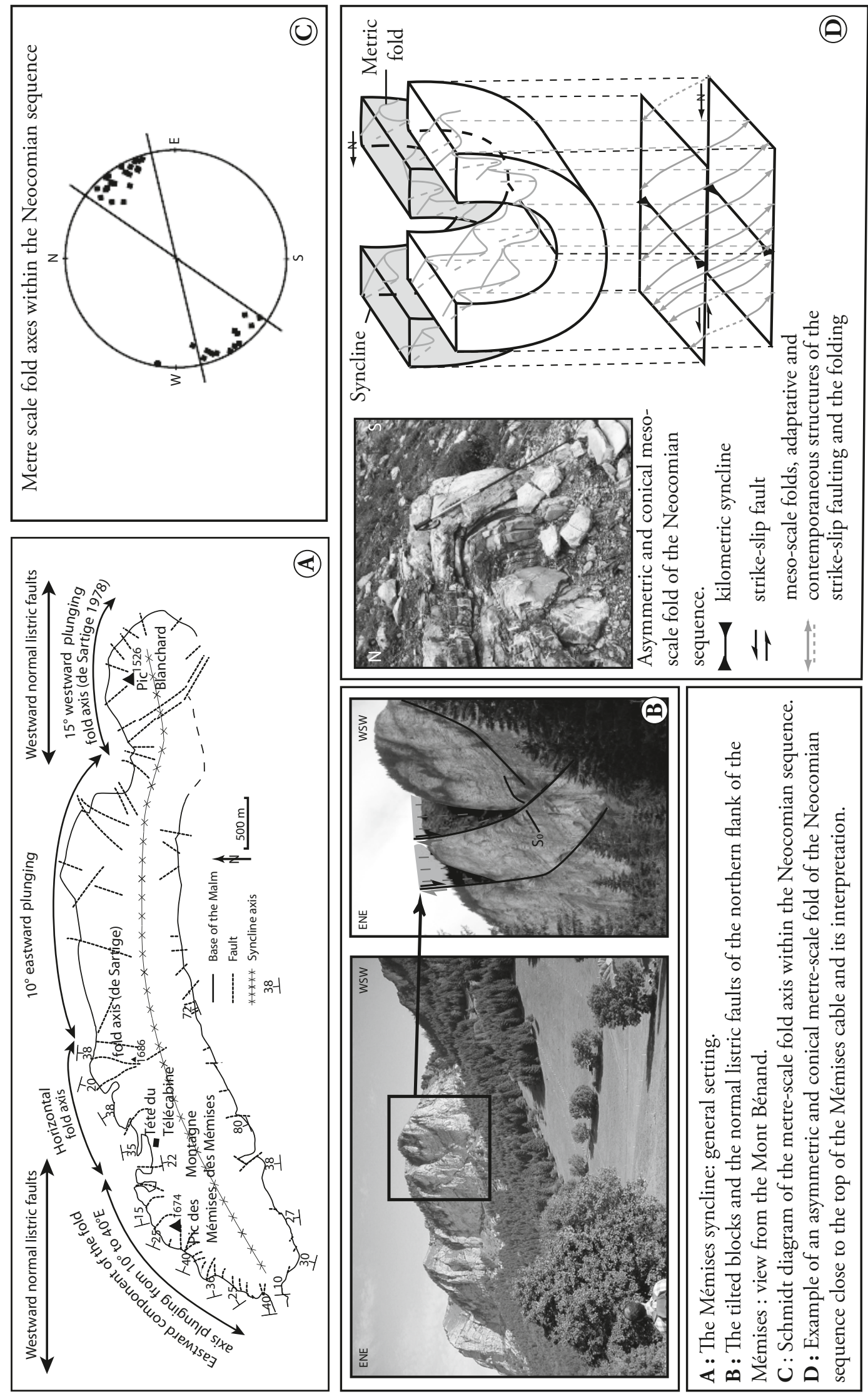


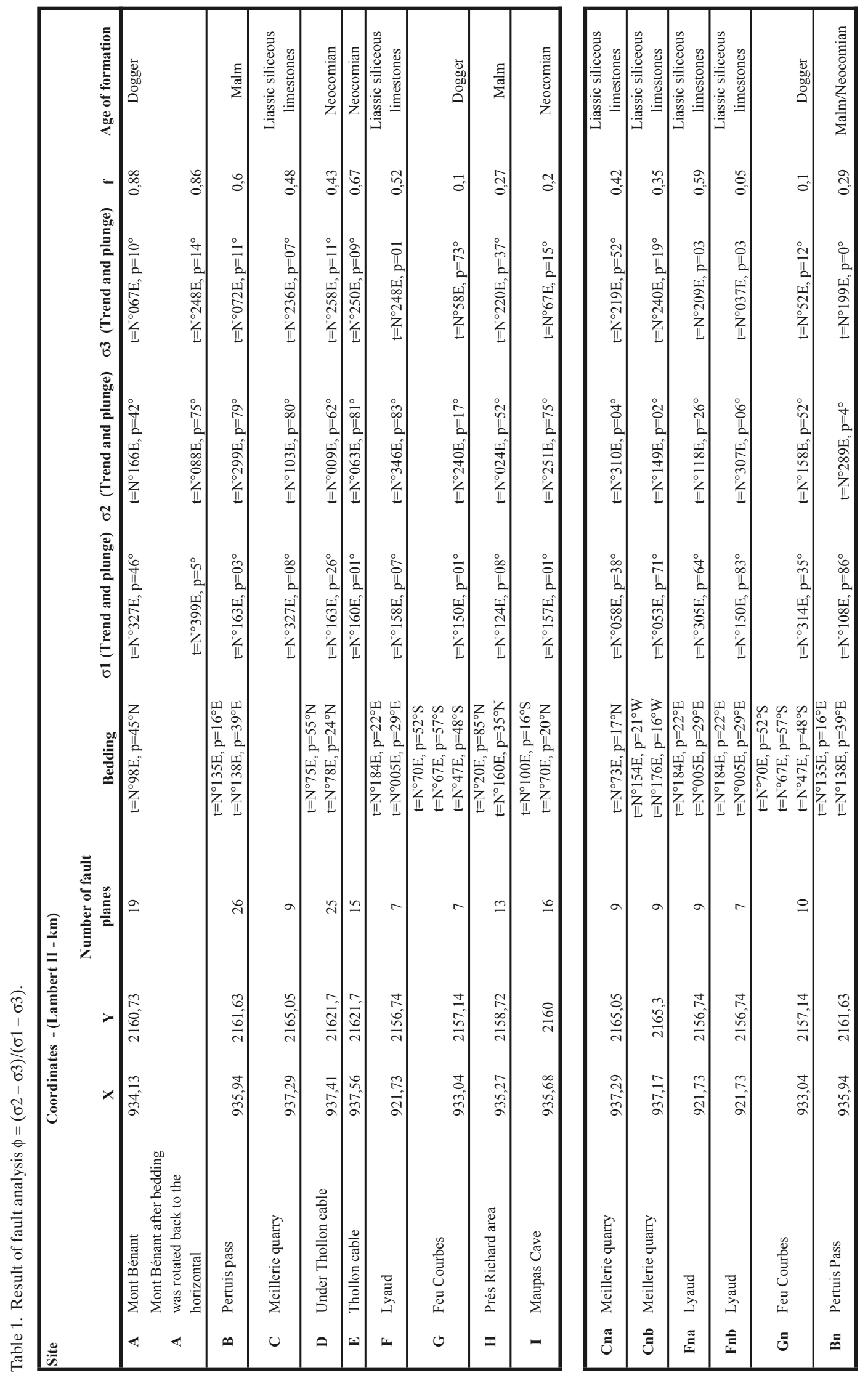

Contemporaneous multi-scale structures in the Montagne des Mémises 9 




Fig. 5. Main results of the fault plane analysis. Equal angle lower hemisphere stereographic projection, with faults and calculated stress axes. A: Mont Bénand; B: Pertuis Pass; C: Meillerie quarry; D and E: Thollon cable; F: Lyaud area; G: Feu Courbes area; H: Pré Richard area; I: Maupas cave.

the other is vertical. This is compatible with the near surface orientation of stress axes that is either parallel or perpendicular to earth's surface. The orientations of the stress axes are similar from one locality to another, despite the wide variety of bedding plane orientations, showing that stress orientation and faulting were not governed by structure. As the striations 


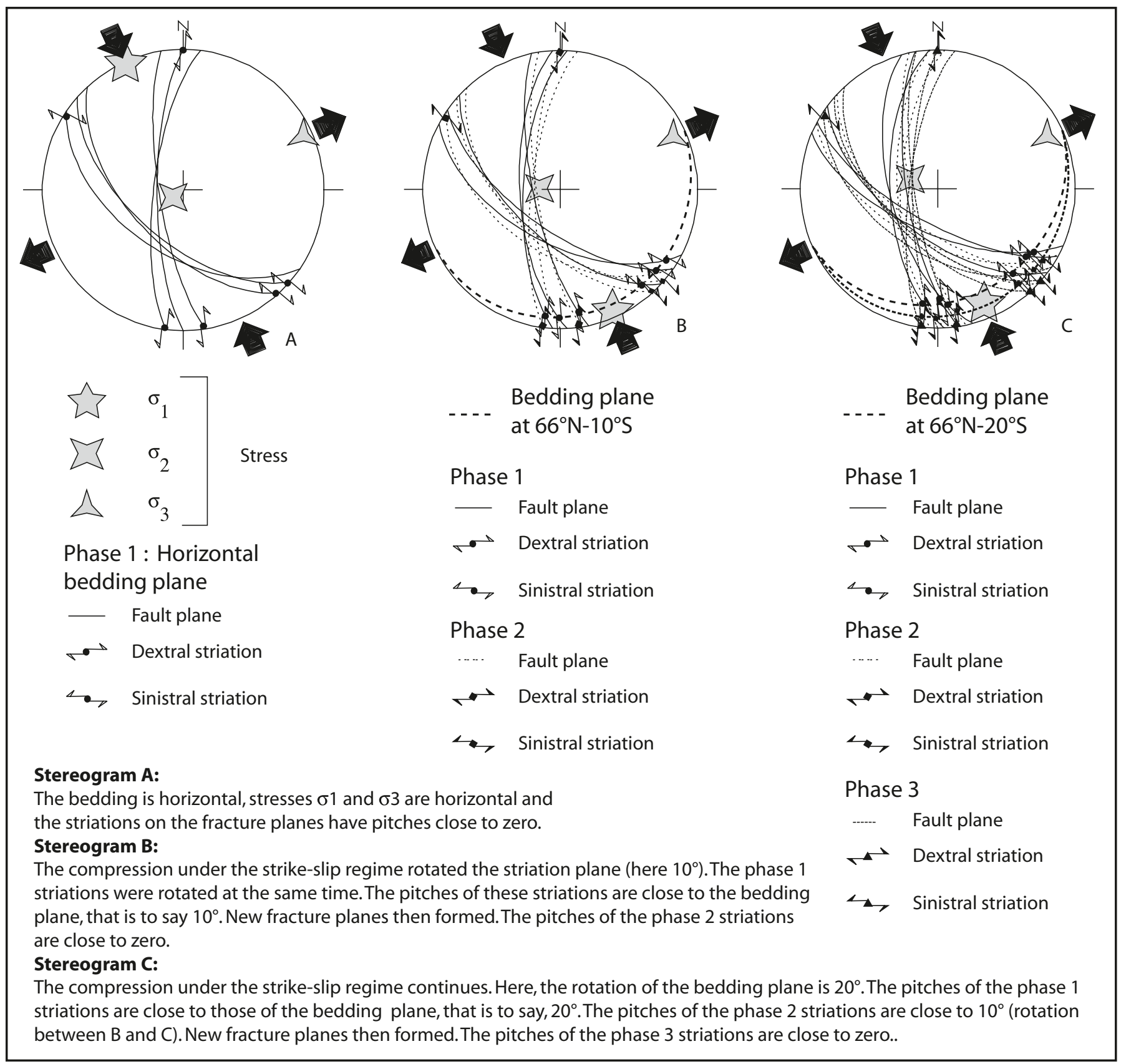

Fig. 6. Evolution of the striation.

on the strike-slip faults are almost horizontal, and because the paleostress axes have not been rotated by folding, we can infer that this stress regime postdates the folding.

A similar stress regime was found at localities A, C, D and F, but here the principal stress axes are not horizontal and vertical (Fig. 5). In diagrams A, C, D and F, $\sigma_{1}$ and $\sigma_{3}$ are along the bedding plane, or between the bedding plane and the horizontal. This consistent relationship indicates that faulting occurred before or during folding. For instance, when faulting occurs along horizontal bedding planes under a strike-slip stress regime, the resulting striations and paleostresses are similar to those described as phase 1 in Fig. 6, that is to say, the striations and the two stress axes are horizontal. If folding occurs, previous fractures are tilted but striation due to the constant stresses still occurs horizontally. Hence, typical syn-folding striations are obtained and the pitch of the slickensides varies from horizontal to parallel to the bedding plane (Fig. 6). The average syn-folding stress tensor reconstructed from the Mémises faults shows characteristic tilted stress axes. In summary, when plotted in stereographic projection, we have: 


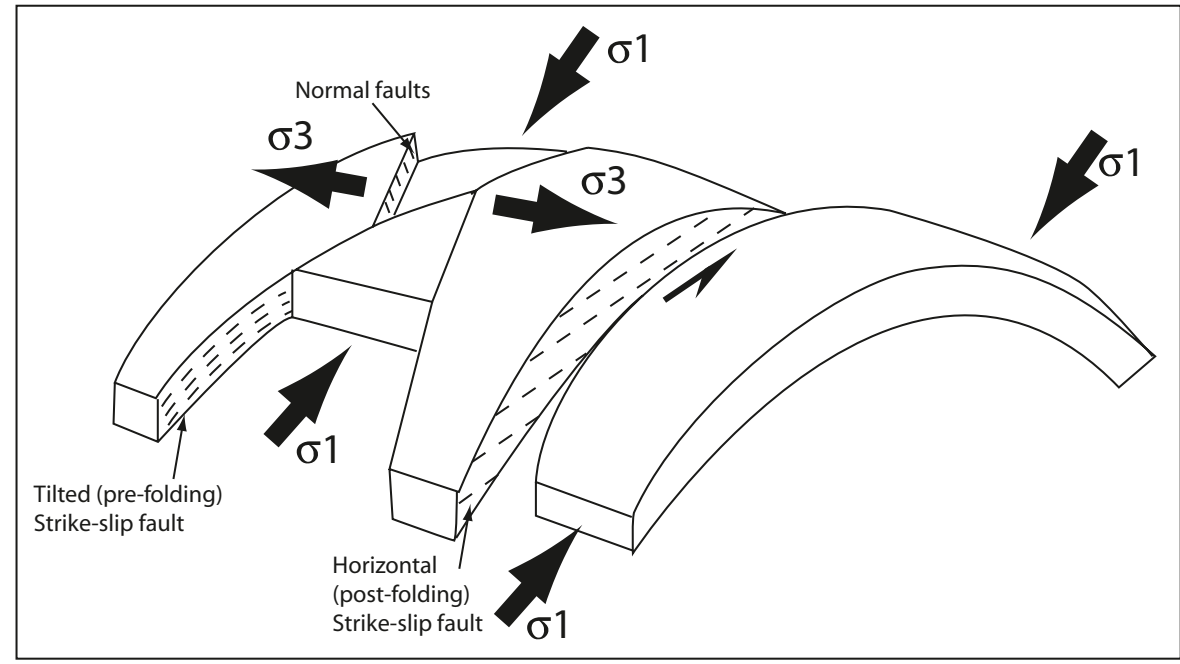

Fig. 7. Structural relationship between folding, faulting and the principal stress axes.
1) In the case of the syn-folding strike-slip faulting, the slickensides and the $\sigma_{1}$ axes lie between the bedding plane (great circle) and the horizontal.

2) In the case of the post-folding strike-slip faulting, the slickensides and the $\sigma_{1}$ axes are horizontal.

Diagrams A and D (Fig. 5) indicate syn-folding striation and stress regimes. This is probably also the case for diagrams $\mathrm{C}$ and $\mathrm{F}$, although it is more difficult to draw a firm conclusion because of the low dip.

It could be argued that an alternation of strike-slip faulting and compressive folding would produce a similar result. However, such a multi-phase solution is probably too complex to be realistic and we therefore favour the syn-folding hypothesis.

These diagrams suggest that the faulting in the Montagne des Mémises was contemporaneous with the large-scale folding, which is compatible with other paleostress studies in the Préalpes Romandes (Mosar \& Borel 1992), where a similar strikeslip regime was characterized using the right dihedra method. However, previous studies did not include bedding plane orientations, thereby limiting the comparisons that can be made with our results. Two types of stress regime have been recognised in Late Miocene rocks in the Jura Mountains (Homberg 1997, Homberg et al. 2002): a strike-slip regime $\left(\sigma_{1}=\mathrm{NW}-\mathrm{SE}\right.$ and $\left.\sigma_{3}=\mathrm{NE}-\mathrm{SW}\right)$ and a reverse regime $\left(\sigma_{1}=\mathrm{NW}-\mathrm{SE}\right.$ and $\sigma_{2}=\mathrm{NE}-\mathrm{SW}$ ). Due to the low dip of the bedding planes, it was impossible to carry out such an analysis for the Montagne des Mémises localities.

\subsubsection{Extensional stress regime}

Six of the diagrams in Fig. 5 (Bn, Cna, Cnb, Fna, Fnb, Gn) show an extensional stress regime. In diagrams $\mathrm{Bn}$ and Fnb the stress axes are vertical and horizontal; in the other four diagrams the stress axes are tilted. In all six cases the extension is from NNE-SSW to NE-SW. This extension direction is similar to the $\sigma_{3}$ trend of the strike-slip regime (e.g., Cna and Cnb, Fig. 5), suggesting that these two stress regimes are related through a simple stress permutation, with a switch of the $\sigma_{1}$ and $\sigma_{2}$ axes, and $\sigma_{3}$ remaining constant.

It should also be noted that some of the diagrams show vertical and horizontal stress axes (e.g., Bn and Fnb), whereas others show tilted stress axes (e.g., Cna, Gn). The former correspond to post-tilt faulting, while the later correspond to pre-tilt faulting. As for the strike-slip stress regime, they indicate that faulting occurred during folding.

As this extensional deformation was observed only on the northern edge of the folds (Mémises syncline for Bn, Cna and Cnb; De Lyaud anticline for Fna and Fnb; Vacheresse anticline for $\mathrm{G}$ ), we believe that it corresponds to local stress permutations (of $\sigma_{1}$ and $\sigma_{2}$ ) and that extension occurred during folding. The only Cretaceous normal fault in the area (Hable 1997) runs parallel to the axis of the syncline and is thus different from the normal faults described here. This indicates that the normal faults in the Mémises syncline are of Alpine or post-Alpine age (Mosar 1999, Champagnac 2004). Moreover, the faults, the stress tensors and bedding plane relationships clearly show that the normal faulting described here occurred before the folding (e.g., Fna), during the folding (e.g., Bn) and after the folding (e.g., Fnb).

It has been shown that a change from one stress regime to another may be brought about by simple permutation of the $\sigma_{1}$ and $\sigma_{2}$ stress axes, as occurred here between the strike-slip and the extensional stress regimes. (Angelier \& Bergerat 1983). This type of stress permutation can occur during a single tectonic event (Hippolyte et al. 1992). Similarly, we propose that both the strike-slip and normal faulting in the Montagne des Mémises occurred during the same large-scale folding event.

Similar extension, parallel to the fold axes (like $\sigma_{3}$ ), has been observed in the Préalpes Romandes (Mosar 1991, Mettraux \& Mosar 1989) and in the Jura (Homberg 2002), but in these cases it was not possible to analyze the bedding plane-faulting rela-

12 A. Guyomard et al. 
tionships. In the Montagne des Mémises, the relation between the bedding planes and the faulting suggests that the faulting was contemporaneous with the folding. In the Jura, normal faulting in horizontal bedding planes has been interpreted as being related to the Oligocene extension (Homberg 2002). Even though the Montagne des Mémises lies just on the other side of the Molasse Basin to the Jura, such an interpretation is not possible here, as the Alpine thrust units were decoupled from their foreland and from the Jura when the Molasse Basin was active. Our analysis of striated faults indicates a different interpretation for the normal faulting observed in the Montagne des Mémises. In addition, extensional structures associated with large strike-slip faults, similar to the tilted blocks of the Montagne des Mémises, have been identified by microstructural analyses within the sub-Alpine Aravis Massif (Danet 2003).

\subsection{The age of the observed structures}

We do not have any direct data on the ages of the observed structures. We can only say that the Eocene extension demonstrated by Hable (1997) occurred prior to this deformation and that erosion and exhumation took place after the deformation.

Further east, in the Préalpes Romandes, Mosar (1988a-b, $1989,1991)$ has shown that the deformation of the Prealps was a multi-phase process. In our study area, there is no evidence of an earlier phase of deformation to the one studied here, but we do not know whether this is because there was no such earlier phase or because the effects of the earlier deformation have been masked by more recent events. This raises the question of whether the Montagne des Mémises is structurally distinct or whether similar studies in the frontal part of the Préalpes Romandes would give equivalent results.

\section{Conclusion}

Analyses of fault-slip data and paleostress reconstructions show that most of the faulting in the Mémises area is related to a strike-slip compressional regime with $\sigma_{1}$ trending from $\mathrm{N} 150^{\circ} \mathrm{E}$ to $\mathrm{N} 160^{\circ} \mathrm{E}$. This regime also produced the area's large-scale folds and small-scale conical folds. Some of the fault sites have provided sufficient data to show that the strike-slip faulting and tilting were contemporaneous. Reverse faulting was not found, probably because the shortening was mostly absorbed by the folding.

A small proportion of the fault planes measured indicate the occurrence of local normal faulting, at different scales, in particular along the northern edge of the folds. This extension is also contemporaneous with the folding deformation and is the result of stress permutation between the $\sigma_{1}$ and $\sigma_{2}$ axes, with $\sigma_{3}$ remaining constant for both the strike-slip and extensional regimes.

The folding of the Préalpes du Chablais took place under a strike-slip, and locally extensional, stress regime with a com- mon orientation of the maximum principal stress axis $\left(\sigma_{1}\right.$ or $\sigma_{2}, \mathrm{~N} 150^{\circ} \mathrm{E}$ to $\mathrm{N} 160^{\circ} \mathrm{E}$ ). The small-scale conical folds were created by strike-slip faulting with $\sigma_{1}$ also trending $\mathrm{N} 150^{\circ} \mathrm{E}$ to $\mathrm{N} 160^{\circ} \mathrm{E}$.

\section{REFERENCES}

Angelier, J. 1990: Inversion of field data in fault tectonics to obtain the regional stress - III. A new rapid direct inversion method by analytical means. Geophysical Journal International 103, 363-376.

Angelier, J. 1991: Inversion directe et recherche 4D: comparaison physique et mathématique de deux modes de détermination des tenseurs de paléocontraintes en tectonique de faille. Les Comptes rendus de l'Académie des sciences Paris, Série II. n³12, 1213-1218.

Angelier, J. \& Bergerat, F. 1983: Systèmes de contrainte en extension intracontinentale. Bulletin du Centre de Recherche, d'Exploration et de Production Elf-Aquitaine 7, 137-147.

Badoux, H. 1965: Carte Géologique au 1/50000. Thonon Chatel. Paris, BRGM. Service de la carte Géologique de France.

Badoux, H. \& Mercanton, C.-H.1962: Essai sur l'évolution tectonique des Préalpes médianes du Chablais. Eclogae Geologicae Helvetiae 55, 135-188.

Borel, D.G. \& Mosar, J. 2000: Subsurface structures in the Chablais Préalpes: New tectonic interpretations of the Préalpes Médianes nappe based on palinspastic lengths. Eclogae Geologicae Helvetiae 93, 307-314.

Champagnac J.-D. 2004: Tectonique cassante de l'arc interne des Alpes occidentales. Implications géodynamiques. Thèse, Universités de Neuchâtel et de Grenoble, 222 pp.

Danet, J. 2003: Caractérisation et interprétation de la déformation extensive dans la chaîne des Aravis (Massif des Bornes). Université Joseph Fourrier, Grenoble, Mémoire de DEA 32, unpubl.

Delacou, B., Deichmann, N., Sue, C., Thouvenot, F., Champagnac, J.-D. \& Burkhard, M. 2005: Active strike-slip faulting. in the Chablais area (NW Alps) from earthquake focal mechanisms and relative locations. Eclogae Geologicae Helvetiae 98, 189-199.

Etchecopar, A., Vasseur, G. \& Daignieres, M. 1981: An inverse problem in microtectonics for the determination of stress tensors from fault striation analysis. Journal of Structural Geology 3, 51-63.

Guyomard, A. 2006: Etude structurale et hydrogéologique de la terminaison occidentale du Massif des Mémises et de ses relations avec le complexe détritique quaternaire d'Evian, Thèse, Université de Savoie, Chambéry, $330 \mathrm{pp}$.

Hable, R. 1997: Biostratigraphie, Sedimentologie und paläogeographische Entwicklung der Préalpes médianes des Chablais (Haute-Savoie) von Apt bis Unter-Eozän. Thèse, Université de Fribourg, 324 pp.

Hippolyte, J.-C., Angelier, J. \& Roure, F. 1992: Les permutations d'axes de contraintes: exemples dans des terrains quaternaires de Sud de l'Apennin (Italie). Comptes rendus de l'Académie des sciences. Paris, T.315, Série II, 89-95.

Homberg, C., 1997: Analyse des déformations cassantes dans le Jura et modélisation numérique des perturbations des contraintes tectoniques autour d'accidents majeurs. Thèse, Université Pierre et Marie Curie, Paris, $306 \mathrm{pp}$.

Homberg, C. Bergerat, F. Philippe, Y. Lacombe, O. Angelier, J. 2002: Structural inheritance and Cenozoic stress fields in the Jura fold-and-thrust belt (France). Tectonophysics 357, 137-158.

Lugeon, M, \& Gagnebin, E. 1941: Observations et vues nouvelles sur la géologie des Préalpes romandes. Bulletin des laboratoires de géologie, minéralogie, géophysique et du Musée géologique de l'Université de Lausanne $72,1-90$.

Mettraux, M. \& Mosar, J. 1989: Tectonique alpine et paléotectonique liasique dans les Préalpes Médianes en rive droite du Rhône. Eclogae Geologicae Helvetiae 82, 517-540.

Mosar, J. 1988-a: Métamorphisme transporté dans les Préalpes. Schweizerische Mineralogische und Petrographische Mitteilungen 68,77-84.

Mosar, J. 1988-b: Structures, déformation et métamorphisme dans les Préalpes Romandes (Suisse). Thèse, Université de Neuchâtel. 
Mosar, J. 1989: Déformation interne dans les Préalpes médianes (Suisse). Eclogae Geologicae Helvetiae 82, 765-793.

Mosar, J. 1991: Géologie structurale dans les Préalpes médianes (Suisse). Eclogae Geologicae Helvetiae 84, 689-725.

Mosar, J. 1994: Géologie structurale à l'est de Montreux (Préalpes médianes plastiques, Suisse). Eclogae Geologicae Helvetiae 87, 11-32.

Mosar, J. 1997: Folds and thrusts in the Préalpes Médianes Plastiques Romandes. Bulletin de la Société vaudoise des sciences naturelles 84, 347-384.

Mosar, J. 1999: Present-day and future tectonic underplating in the Western Swiss Alps: reconciliation of basement/wrench-faulting and decollement folding of the Jura and Molasse basin in the Alpine foreland. Earth and Planetary Science Letters 173, 143-155.

Mosar, J. 2002: Préalpes Klippen-Belt. Neotectonics-Morphotectonics and Geodynamic evolution: Université de Fribourg, 13. unpubl (Projet de recherche).

Mosar, J. \& Borel, D.G. 1992: Paleostress from the Préalpes médianes (Switzerland). Annales Tectonicae 6, 115-113.

Mosar, J. \& Borel, D.G. 1995: The Préalpes. References on the geology: http:// www-sst.unil.ch/research/prealps/REFPAPER.htm.

Mosar, J., Stampfli, G.M. \& Girod, F. 1996: Western Préalpes Médianes Romandes: Timing and structure. A review. Eclogae Geologicae Helvetiae 89, 389-425.

Plancherel, R. 1976: Essai d'interprétation de la dislocation transversale de Bellegarde-lac Noir (Préalpes médianes fribourgeoises). Eclogae Geologicae Helvetiae 65, 461-469.
Plancherel, R. 1979: Aspects de la déformation en grand dans les Préalpes Médianes plastiques entre Rhône et Aar. Eclogae Geologicae Helvetiae $72,145-214$.

Plancherel, R. 1990: Les Préalpes du Chablais - Présentation générale. In: Suisse Lémanique pays de Genève et Chablais. Guides Géologiques Régionaux. (Ed: by Charollais, J. \& Badoux, H.), Masson, Paris, 183-190.

Plancherel, R. \& Weidmann, M. 1972: La zone anticlinale complexe de la Tinière (Préalpes Médianes Vaudoises). Eclogae Geologicae Helvetiae 65, 75-91.

Raymond, D., Deffontaines, B., Ferhi, A., Dorioz, J.M. \& Rudant, J.P. 1996.: Néotectonique de la région sud-lémanique (Haute-Savoie, France): Approche multisources (imagerie optique et hyperfréquences, analyse morphostructurale). Eclogae Geologicae Helvetiae 89, 949973.

Sartiges, B. 1978: Infiltration des eaux et relations entre aquifères profonds et superficiels: Hydrogéologie du plateau de Thollon, de la montagne de Mémise et de la vallée d'Ugine (Haute-Savoie), Thèse Université Joseph Fourrier, Grenoble, 275 pp.

Manuscript received August 2, 2007

Revision accepted October 16, 2008

Published Online first April 7, 2009

Editorial Handling: Stefan Bucher

14 A. Guyomard et al. 